maciej.czerwinski@uj.edu.pl

\title{
Dysydent Bogdan Radica
}

\begin{abstract}
Czerwiński Maciej, Dysydent Bogdan Radica (A Dissident Bogdan Radica). „Poznańskie Studia Slawistyczne” 6. Poznań 2014. Publishing House Science and Innovate, pp. 75-90. ISBN 978-83-63795-51-1. ISSN 2084-3011.

In the article a certain prominent Croatian emigrant, but very little known in Croatia, is taken into consideration. Bogdan Radica (1904-1993) was a political dissident in two different circumstances. Between 1941-1945, as an attaché of the Yugoslav Embassy in Washington, he was opposing both the Ustasha'a Croatian state and Yugoslav policy under Serbian control, which he defined as a hegemonic and 'anti-Yugoslav'. Between 1945-1993, with a short period supporting the Communists, he became the most prominent representative of the Croatian emigration, emphasizing pro-independent attitudes. His engagement is seen not as an ideological profile but as an attitude.
\end{abstract}

Keywords: Bogdan Radica; Croatian emigration; exile; liberal thought; independence; communism; fascism; dissidence

Gdyby wpływ jednostek na kształtowanie się tożsamości narodów sytuujących się na pograniczach różnych cywilizacji mierzyć ich odnotowanymi przez słowo pisane kontaktami z ważnymi osobistościami europejskiej kultury i polityki, wówczas Bogdan Radica musiałby zostać zapewne uznany za jednego z najważniejszych Chorwatów w historii. Ponieważ jednak miara znaczenia w danej kulturze nie kończy się na wspomnianym czynniku, lecz oddziałują na nią również inne zmienne, słabą obecność Radicy w chorwackiej wyobraźni historycznej należy potraktować jako zjawisko odrębne, domagające się refleksji. Jak bowiem wytłumaczyć zupełny niemal brak wiedzy o istnieniu intelektualisty, który przed drugą wojną światową przyjaźnił się i/lub prowadził rozmowy z takimi osobistościami, jak Thomas Mann, Benedetto Croce, Nikołaj Bierdiajew, Paul Valéry, Guglielmo Ferrero, André Gide, José Ortega y Gasset, Julien Benda, Giovanni Papini, François Mauriac, Jacques Maritain, Maksim Gorki, Filippo Tommaso 
Marinetti? ${ }^{1}$ Jak zrozumieć zupełną marginalizację kogoś, kto był świadkiem najważniejszych wydarzeń dla Chorwacji i Jugosławii w XX wieku, będąc najczęściej w samym ich centrum? Jak wytłumaczyć nieobecność kogoś, kto udokumentował w swoich wspomnieniach najistotniejsze momenty w dwudziestowiecznej historii, a także - w esejach - wykreował wyjątkową, może nawet najbardziej ciekawą, wizję Śródziemnomorza w chorwackiej kulturze? Odpowiedź na takie pytania pozostawić należy na inną okazję, gdyż ważniejsze jest w tym momencie przybliżenie tej tajemniczej postaci oraz jej aktywności na polu kultury i polityki.

Działalność Radicy, wymuszoną skądinąd przez okoliczności, trzeba potraktować jako kompromis pomiędzy wewnętrzną potrzebą działania, dyktowaną patriotyzmem i poczuciem obywatelskiej odpowiedzialności a ciągłym widmem konieczności wyboru jakiegoś „mniejszego zła”. W takiej beznadziejnej sytuacji dysydenctwo staje się nie tylko postawą kontestacji konkretnego systemu władzy (w przypadku Radicy - jugosłowiańskiego, ustaszowskiego i komunistycznego), lecz także swojego rodzaju światopoglądem. W sensie zaś bardziej ogólnym - metaforą losu ludzkiego w czasach politycznych zawieruch i moralnych niepokojów.

\section{Bogdan Radica}

Urodził się w Splicie w 1904 roku, zmarł w Nowym Jorku w roku 1993. Był publicystą i eseistą, poliglotą i thumaczem, działaczem społecznym, profesorem uniwersyteckim. W latach 20. XX wieku pracował jako dziennikarz prasy jugosłowiańskiej we Włoszech ${ }^{2}$, a następnie od roku 1929 jako korespondent agencji informacyjnej Avala w Atenach. Od połowy lat 30. podejmował służbę w poselstwach i ambasadach Królestwa Jugosławii, m.in. w Genewie przy Lidze Narodów. W roku 1939 roku wrócił do Belgradu, gdzie miał zostać powołany na stanowisko szefa biura informacyjnego rządu uformowanego w rezultacie porozumienia Cvetković-Maček, ale pod naciskami Włoch (a konkretnie na wniosek ministra spraw zagranicznych Galeazzo Ciano) - które zarzucały mu bliskie

${ }^{1}$ Część tych wywiadów opublikował w książce Agonia Europy. Pierwsze wydanie ukazało się w Belgradzie w 1940 roku, a kolejne trzy - również w Belgradzie - w latach 90. XX wieku. Chorwackie wydanie pojawiło się dopiero w 2006 roku.

2 Pisywał do takich czasopism, jak „Hrvatska riječ”, „Nova Europa” i „Obzor”. 
kontakty i pokrewieństwo duchowe z antyfaszystowską inteligencją - decyzja ta została cofnięta. Ostatecznie Radicę mianowano attaché odpowiedzialnym za politykę informacyjną w ambasadzie jugosłowiańskiej w Waszyngtonie.

Do wtedy był zwolennikiem idei jugosłowiańskiej (ukształtowało go środowisko splickie o sympatiach bliskich pozycjom Ante Trumbicia, którego zresztą znał osobiście od najmłodszych lat). Idea ta jawiła się jako koncepcja kulturalna i polityczna, ale - zgodnie z postulatami członków Komitetu Jugosłowiańskiego - niekwestionująca istniejących różnic między Chorwatami i Serbami ${ }^{3}$. Z powodu rozczarowania rolą tych ostatnich we wspólnym państwie Radica z czasem zdystansował się od Jugosławii, a od roku 1940 zaczął coraz bardziej akcentować chorwackość, choć wciąż w ramach zmodyfikowanej idei jugosłowiańskiej. W Waszyngtonie - będąc w konflikcie z ambasadorem Konstantinem Foticiem, który jego zdaniem propagował serbski nacjonalizm - ukształtowała się ostatecznie jego nieufność, a później także awersja do serbskiej wizji Jugosławii. Dokonało się to mniej więcej w tym samym czasie co u rzeźbiarza Ivana Meštrovicia. Można więc powiedzieć, że byli oni - Meštrović i Radica - epigonami poglądów dawnego Komitetu Jugosłowiańskiego (Trumbić odszedł od nich znacznie wcześniej).

Idea wspólnoty południowych Słowian nie umarła jednak w Radicy od razu. Od roku 1943, mimo swojego antykomunistycznego światopoglądu (odziedziczonego przede wszystkim po środowisku rodzimym), zaczął oficjalnie, także w prasie amerykańskiej, popierać partyzantów Josipa Broza Tity. Dostrzegał w tym ruchu szansę na pokonanie opcji wielkoserbskiej oraz na zbudowanie Jugosławii bardziej sprawiedliwej niż przedwojenna. W następstwie takiego wyboru powrócił w roku 1945 do Belgradu, gdzie miał zostać sekretarzem stanu w jednym z ministerstw rządu formowanego przez komunistów, ale popieranego i współtworzonego przez nie-komunistów z królewskiego gabinetu londyńskiego ${ }^{4}$ i przez część inteligencji emigracyjnej. Kilkumiesięczny pobyt w Jugosławii, od kwietnia do października 1945 roku, pozbawił go jednak złudzeń. Jego zdaniem, komuniści nie dość, że nie zamierzali wówczas odstąpić od polityki ,wielkoserbskiej” (mimo iż Tito był

${ }^{3} \mathrm{~W}$ języku polskim dostępne są publikacje dotyczące okresu formowania się idei jugosłowiańskiej i jej upadku: por. np. Benson 2011; Jelavich 2005; Felczak i Wasilewski 1985; Rapacka 1995; Tanty 1968, 2003.

${ }^{4}$ Porozumienie takie zostało zawarte na wyspie Vis w 1944 roku między J.B. Titą a I. Šubašiciem. 
po ojcu Chorwatem, a po matce Słoweńcem), to nadto nie mieli szacunku dla demokracji i stosowali terror, czego był naocznym świadkiem. Okoliczności przejmowania przez komunistów władzy opisał we wspomnieniach, obejmujących dzienniki z okresu 1944-1946 (Radica 1974).

Po powrocie do USA, wcale niełatwym ze względu na sytuację w komunistycznym kraju, rozpoczął się nowy okres w życiu Radicy. Przez niemal czterdzieści lat, aż do śmierci, był najważniejszym działaczem chorwackiej emigracji. Rozczarowania wynikające z zaangażowania w budowanie Jugosławii - najpierw monarchistycznej, a następnie komunistycznej - stały się piętnem na tyle wyrazistym, że ukształtują jego jaskrawo negatywny stosunek zarówno do komunizmu Tity, jak i do możliwości reaktywacji jakiegokolwiek nowego państwa jugosłowiańskiego. Pozostanie już do końca wierny programowi niepodległościowemu. Pogląd ten doprowadził go zresztą do konfliktu z przywódcą Chorwackiej Partii Chłopskiej (HSS) Vladko Mačkiem oraz do bliższej współpracy z ludźmi wywodzącymi się ze zreformowanych środowisk ustaszowskich.

Aby w pełni zrozumieć rolę Bogdana Radicy w chorwackiej kulturze, konieczne są dogłębne badania historyczne, uwzględniające nie tylko okoliczności społeczno-polityczne, w jakich działała ówczesna emigracja, ale również sytuację wewnętrzną w USA i stosunki dyplomatyczne między aliantami oraz relacje łączące emigracje różnych narodów wschodnioeuropejskich. Sięgnięcie po różne źródła może dać odpowiedź na pytanie, jaką pozycję miał Radica w tamtym czasie i dopiero wtedy należałoby próbować oceniać słuszność jego wyborów politycznych. Cel niniejszego artykułu, otwierającego cykl studiów poświęconych Radicy, jest skromniejszy - to próba spojrzenia na postać z punktu widzenia preferowanego przez nią dyskursu, uosabiającego pewien kod kulturowy, który narodził się w odpowiedzi na ówczesny kontekst polityczny.

W sferze deklaratywnej Radica nie był ani zwolennikiem faszyzmu ani komunizmu, choć skrajna prawica określała go mianem komunisty lub jugoslavena (czasem nawet - nawiązując do epiki ludowej - jug-bogda$\left.n a^{5}\right)$, komuniści zaś i środowiska serbskie widziały w nim ustaszę. Przed drugą wojną światową i w jej trakcie wyrażał otwarcie zarówno poglądy

5 Jug Bogdan jest bohaterem serbskiej epiki ludowej cyklu przedkosowskiego i kosowskiego (odpowiada postaci historycznej - Vratkowi Nemanjiciowi). Nazwanie Radicy jug-bogdanem ma na celu podkreślenie jego proserbskiej i antychorwackiej orientacji. 
antyfaszystowskie, jak i antykomunistyczne, czego dowodzą nie tylko wspomnienia, ale także teksty i wywiady opublikowane w roku 1940 w książce Agonia Europy (Radica 2006). Rodowód pokrewieństwa duchowego z tradycjami liberalno-demokratycznymi w Europie, wyrażającymi się poprzez krytykę faszyzmu, wynikał zapewne także z wpływu, jaki wywarł nań ojciec jego żony Niny - włoski historyk, znany antyfaszysta Guglielmo Ferrero.

Tak jak antyfaszyzm nie pomógł mu uniknąć późniejszej współpracy ze środowiskami, które wcześniej współtworzyły scenę kulturalną NDH, tak i antykomunizm nie uchronił go przed krótkotrwałym wspieraniem władzy ludowej. Jednakże doktrynalny brak zgody na propagowanie jakiejkolwiek ideologii totalitarnej zrodził w nim ducha negacji, więc dysydenctwo okaże się jedyną możliwością na prowadzenie uczciwej działalności społecznej i politycznej.

\section{Dysydent - pierwsze otwarcie: 1941-1945}

Wspomnienia Bogdana Radicy Živjeti nedoživjeti (Radica 1982, 1984) są nieocenionym źródłem informacji na temat okoliczności, w jakich znaleźli się działacze jugosłowiańscy w czasie drugiej wojny światowej i po jej zakończeniu, reprezentujący odmienne środowiska narodowe i polityczne. Aby móc zrozumieć kompleksowość tej sytuacji, należy przypomnieć, że okres przedwojenny, w tym również okoliczności wojenne na terenach okupowanych, doprowadziły do zaostrzenia się konfliktów między Chorwatami i Serbami. Zrodziły one zespół wzajemnych uprzedzeń, jak czas pokaże - niemożliwych do przezwyciężenia. Chorwaci zarzucali Serbom konsekwentne hołdowanie ideologii wielkopaństwowej, czego realizacją miała być pierwsza Jugosławia, z gruntu - antychorwacka. Z kolei Serbowie widzieli w Chorwatach notorycznych zdrajców, sługusów Niemców i Watykanu, niewdzięcznych za wkład Serbów w wyzwolenie ich spod tyranii obcych. To zaś miało być - jak dowodziły środowiska serbskie - powodem przystąipienia Chorwatów do wojny po stronie państw Osi, a Serbów pozwalało przedstawić jako sojuszników Francji i Wielkiej Brytanii, czyli zwolenników wolności i demokracji ${ }^{6}$.

${ }^{6}$ Obie narracje historyczne nawiązywały do już istniejących w wyobraźni historycznej przekonań na temat zjednoczenia Jugosławii (Czerwiński 2012a). 
Tak skrajne wizje rzeczywistości niweczyły możliwość kompromisu, co doskonale dokumentują wspomnienia Radicy. Podczas pobytu w USA, gdzie skupiały się różne nurty emigracji, zetknął się z beznadziejnością tej sytuacji. Jego zdaniem, znaczna część serbskich polityków propagowała przekonania antychorwackie albo otwarcie antyjugosłowiańskie i wielkoserbskie (jak np. ambasador Fotić). Według Radicy obie opcje dążyły do oczernienia Chorwatów w oczach amerykańskiej opinii publicznej i zrzucenia na nich odpowiedzialności za wojnę domową w Jugosławii ${ }^{7}$. Ponieważ takiemu obrazowi sprzyjały fakty (zbrodnie ustaszy z jednej strony oraz opór wojsk królewskich Dražy Mihailovicia z drugiej $^{8}$ ) opinia o Chorwatach była na ogół negatywna.

Już wkrótce, zwłaszcza po stworzeniu przez Pavelicia państwa w Zagrzebiu, z Chorwacji pozostanie biedne i śmieszne państewko satelickie Hitlera i Mussoliniego - wskazywane jako wzorzec najbardziej krwawego reżimu, który istniał w czasie wojny. Było jasne, że jeśli się wśród Chorwatów i na ziemiach chorwackich nie pojawi ruch, który by choćby częściowo wciągnął naród chorwacki do wojny przeciw państwom Osi, to skazałoby go to na ogromne niepowodzenia w następstwie zdarzeń historycznych (Radica 1984: 110) ${ }^{9}$.

Z powodu tej dramatycznej sytuacji Radica - w pierwszej fazie swojej służby dyplomatycznej zajmujący się przede wszystkim wykonywaniem obowiązków - rozpoczął działalność otwarcie polityczną, mającą na celu zarówno potępienie ustaszy, jak i agitację na rzecz tworzenia pozytywnego wizerunku Chorwatów ${ }^{10}$. Jego celem było przedstawienie chorwackich faszystów jako mniejszości, niereprezentującej całego narodu, ten zaś - jak mniemał - miał stać po stronie Chorwackiej Partii Chłopskiej (HSS) ${ }^{11}$. W ten

${ }^{7}$ Ivan Meštrović - po tym, jak został wypuszczony przez ustaszy z więzienia i opuścił NDH - zauważył, że do podobnych procederów klevetanja Hrvata (Meštrović 1969: 340) dochodziło również w Szwajcarii. Według informacji, które posiadał, artykuły w prasie helweckiej były inspirowane, a nawet finansowane, przez jugosłowiańskie poselstwo zdominowane przez Serbów.

${ }^{8}$ Zanim amerykańska administracja poparła komunistów Tity, wspierała wojska Mihailovicia lojalne wobec królewskiego rządu londyńskiego. W 1943 roku powstał nawet film sławiący bohaterstwo czetników pt. Chetniks! The Fighting Guerillas (scenariusz: J. Andrews, reżyseria: L.H. King, producent: Twenty Century Fox).

${ }^{9}$ Wszystkie thumaczenia - autor niniejszego tekstu.

${ }^{10}$ O kształtowaniu się coraz silniejszej orientacji chorwackiej napisze tak: ,Z dnia na dzień czułem się coraz bardziej Chorwatem. Nie było już innego wyjścia” (Radica 1984: 122).

${ }^{11}$ HSS miała w chorwackim społeczeństwie największe poparcie, a zdaniem historyka Dušana Bilandžicia przed wojną sięgało nawet 93 procent (Bilandžić 1999: 107). 
sposób Radica stał się podwójnym dysydentem: działał zarówno przeciwko ustaszom, jak i rządowi londyńskiemu, któremu służył w randze dyplomaty. Działalność tę otwierają listy do chorwackich polityków (V. Mačka, J. Krnjevicia, I. Meštrovicia) pisane w ostatnich dniach marca 1941 roku, czyli tuż po ogłoszeniu kapitulacji i zamachu stanu w Belgradzie, w których domagał się od nich oficjalnego poparcia króla i rządu jugosłowiańskiego. W liście do Krnjevicia czytamy:

Historyczna odpowiedzialność za interes narodu chorwackiego nakłada na Pana obowiązek, aby jeden członek Rządu, najlepiej Šutej, zamanifestował - tak jak uczynili to Serbowie - niezadowolenie Chorwatów z powodu kompromisu (z państwami Osi). Tylko w taki sposób zaskarbi Pan sobie sympatię (Radica 1984: 104),

a do Meštrovicia:

proszę Pana, aby Pan nakłonił Mačka i Krnjevicia do wzajemnej współpracy w nowych okolicznościach (...). Jeśli Chorwaci tym razem pozostaną obok wydarzeń, będą w przyszłej Europie straceni. Cała opinia publiczna wolnego świata obserwuje Chorwatów. W grę wchodzi honor narodu chorwackiego (Radica 1984: 104).

Postawa taka nie przysporzyła mu zwolenników wśród chorwackich środowisk narodowych, ale usytuowała go jednoznacznie w opozycji do faszymu.

Działalność polityczną i agitacyjną - w tym przede wszystkim korespondencję z chorwackimi i serbskimi politykami, kontakty z dziennikarzami amerykańskimi i publicystykę - uprawiał bez porozumienia z ambasadorem Foticiem.

Ja jednak, działając na własną rękę, informowałem amerykańskich komentatorów politycznych o tym, że Chorwaci ani nie współpracują, ani też nie stoją na stanowisku państw Osi. Co więcej, podkreślałem, że wszelkie informacje o tym, jakoby Chorwaci stali po stronie Osi, były intrygami dyplomacji belgradzkiej, która z państwami Osi współpracuje i ponosi całkowitą odpowiedzialność za politykę zagraniczną Jugosławii (Radica 1984: 104).

W innym miejscu odnotował:

Niektórzy z nas, w tym również Prof. Dinko Tomašić, dążyliśmy jednak ze wszystkich sił do tego, aby przejęcie władzy przez ustaszy w Chorwacji przypisać tylko pewnej 
mniejszości, z którą większość społeczeństwa chorwackiego nie ma nic wspólnego, ani w sensie ideowym, ani też politycznym. Był to jedyny sposób, żeby odciąć naród chorwacki od pełnej odpowiedzialności zarówno za upadek Jugosławii, jak i za ogłoszenie NDH (Radica 1984: 120).

Co więcej, prowadził własną politykę upowszechniania w amerykańskich mediach bieżących informacji z Jugosławii. Wydawał również biuletyn „na našem jeziku”, o którym pisał m.in. „oferuję linię bardziej rozjemczą, która nie stwarzałaby przekonania o całkowitym rozpadzie Jugosławii" (Radica 1984: 125). W listopadzie 1941 roku uczestniczył w zorganizowaniu w Pittsburgu spotkania różnych działaczy chorwackich, którym przyświecał cel integracji niefaszystowskich środowisk narodowych w obliczu powstania NDH.

Stosunek Radicy do zbrodni ustaszy był jednoznacznie negatywny, pisał o „masowych egzekucjach ludności serbskiej w Chorwacji” (Radica 1984: 137) i określał je mianem „rzezi ustaszowskich” (Radica 1984: 132). Można nawet wysunąć hipotezę, że jego poparcie udzielone partyzantce komunistycznej Tity (przy deklarowanym antykomunizmie), wyniknęło z potrzeby przyjęcia skrajnie antyustaszowskiego stanowiska. To z kolei miało na celu przekonanie opinii publicznej o braku poparcia ze strony większości narodu chorwackiego dla reżimu faszystowskiego w NDH. Aby uprzedzić ewentualne zarzuty o sprzyjanie Jugosławii, pisał:

Wielu chorwackich czytelników będzie być może zdziwionych powodem, dla którego zarówno Ban, jak i my wszyscy podkreślamy oddanie i przywiązanie do Jugosławii. Rzecz bardzo łatwo wyjaśnić. Stać na stanowisku niezależnego państwa chorwackiego w tamtym czasie znaczyłoby utożsamienie całego narodu z NDH, które było przez sojuszników uznawane za twór państw Osi (...). Zarówno orientacji wielkoserbskiej, jak i antychorwackiej można się było przeciwstawić wyłącznie z pozycji jugosłowiańskich; była to linia najbardziej logiczna i pragmatyczna (Radica 1984: 225).

Fragment ten, podobnie jak inne cytowane wyżej, jest próbą usprawiedliwienia własnej postawy. Stanowisko prochorwackie i jednocześnie projugosłowiańskie w owym czasie odzwierciedlało przekonania tej garstki Chorwatów, którzy jeszcze nie zdążyli się ostatecznie rozczarować wspólnotą z Serbami. Radica więc, a wraz z nim ban Ivan Šubašić i zapewne Ivan Meštrović, który w tym czasie był więziony przez ustaszy i ledwo uniknął śmierci (Meštrović 1969), są ostatnimi reprezentantami tego światopoglądu. 
Komunistyczna Jugosławia, która powstanie już wkrótce, umożliwi ponownie stworzenie analogicznego konceptu. Będą to jednak zupełnie inni ludzie, wywodzący się z różnych środowisk i odwołujący się do odmiennych tradycji. Można chyba stwierdzić, choć w charakterze hipotezy wymagającej dogłębniejszych badań, że jugosłowiańska orientacja propagowana przez komunistów nie miała tego samego rodowodu intelektualnego co jej przedwojenna odpowiedniczka. Brak tu ciągłości duchowej. Łatwo oczywiście dowieść, że u podstaw obu tych ,jugoslawizmów” legł inny system wartości - wcześniej monarchizm, później komunizm - ale wydaje się, że na tym rzecz się nie wyczerpuje. Poparcie dla komunistów Tity, którego udzielił Radica i wielu innych Chorwatów na emigracji (w tym przede wszystkim Šubašić, wytypowany przez aliantów do przekazania władzy Ticie w imieniu rządu londyńskiego), było jedynym wówczas możliwym rozwiązaniem, o ile oczywiście nie przyjęło się stanowiska odrzucającego jakikolwiek kompromis.

Po stronie partyzantów Radica zaczął stawać od roku 1943. W jednej z swoich analiz pisał w sposób następujący:

Generał Mihajlović jest przedstawicielem dawnego świata, wyłącznie serbskiego. Wraz ze swoimi czetnikami dąży on do odnowienia Serbii pod berłem dynastii. Ma zbyt wąskie horyzonty - zarówno polityczne, jak i socjalne. Nie potrafi znaleźć sposobu, którym mógłby załagodzić spór serbsko-chorwacki. Partyzanci są nośnikami Jugosławii, federacyjnej i demokratycznej, opierają się na Rosji i na Słowiańskości; fakt - są komunistami, ale są wśród nich i tacy, którzy komunistami nie są (Radica 1984: 229).

Ostatecznie przybrany kurs afirmacji Tity zwiększy przewagę HSS W wojnie propagandowej prowadzonej ze środowiskami serbskimi. Ban Šubašić - zwolennik takiej orientacji - zajmował coraz ważniejszą pozycję w polityce Wielkiej Trójki, co zostało przypieczętowane na spotkaniu w Teheranie, a następnie w Jałcie. Ostatecznie to nie Serb, lecz Chorwat - jako premier rządu na wychodźstwie pod patronatem Brytyjczyków - na wyspie Vis przekaże Ticie uprawnienia władzy rządu londyńskiego. Tym sposobem komuniści przejmą „legalnie” - to jest za sprawą podpisanego porozumienia - władzę w Jugosławii.

Radica w swoich wspomnieniach zbyt łatwo, i nazbyt naiwnie, zmianę w polityce Wielkiej Trójki przypisuje roli własnego środowiska. Zupełnie zapomina uwzględnić i to, że wybór Tity jako namaszczonego przywódcy 
nowej Jugosławii, a nie rządu londyńskiego (co było celem Serbów), wynikał z kompromisu zawartego ze Stalinem, dążącego do poszerzenia strefy wpływów sowieckich we wschodniej części Europy. Z perspektywy serbskiej - identyfikującej swój interes narodowy z przedwojenną monarchią - taka decyzja aliantów jest, podobnie jak w Polsce uznanie Manifestu PKWN, traktowana jako zdrada. Fakt, że porozumienie w tej sprawie podpisali dwaj politycy chorwaccy - Ivan Šubašić i Josip Broz Tito - to wystarczający dowód potwierdzający przyjęte założenie. Chorwatów zatem uznaje się za przebiegłych graczy i sprawców przerwania kontinuum państwa przedwojennego oraz utraty należnej Serbom dominacji w ramach federacji socjalistycznej.

\section{Dysydent - drugie otwarcie: 1945-1993}

Okoliczności polityczne oraz sytuacja osobista spowodowały, że kolejne wcielenie w roli dysydenta, które nastąpiło po drugiej wojnie światowej (i kilkumiesięcznym pobycie w Jugosławii rządzonej przez komunistów), miało zupełnie inny charakter niż przedwojenne. Radica bowiem nie pracował już dla żadnego rządu, a emigracja z Jugosławii w 1945 roku była dobrowolna. Reżim komunistyczny chciał wykorzystać jego pozycję międzynarodową, aby autoryzować prowadzoną politykę i stworzyć pozytywny wizerunek państwa socjalistycznego (w ten sam sposób Tito próbował nakłonić do powrotu Meštrovicia). Ponadto Radica w jakimś stopniu odpowiadał profilowi ideologicznemu nowego państwa. Był antyfaszystą, nie uczestniczył w budowaniu NDH, poparł Titę, agitując na rzecz stworzenia wspólnego rządu komunistów z gabinetem londyńskim. Po jego przejściu na pozycje antyjugosłowiańskie i antykomunistyczne, władze ludowe - zarówno w Chorwacji, jak i Serbii - oskarżyły go, podobnie jak innych przeciwników politycznych, o faszyzm.

Po drugiej wojnie światowej Radica koncentrował się głównie na kształtowaniu amerykańskiej i emigracyjnej opinii na temat sytuacji Jugosławii, przede wszystkim w publicystyce; w czasopismach chorwackich, np. „Hrvatski glasnik”, „Hrvatski glas” oraz np. w „Reader's Digest”, „The Commentary”, „The Statesman” czy „The New York Times”. Jako naoczny świadek zaprowadzania rządów komunistycznych w Jugosławii - które 
opisał w wersji rozbudowanej (Radica 1974) oraz skróconej (Radica 1984) - był wielokrotnie przesłuchiwany przez komisje ds. bezpieczeństwa amerykańskiego Kongresu. Wspomnienia Živjeti nedoživjeti są świadectwem jego licznych kontaktów z różnymi nurtami emigracyjnymi, przede wszystkim z najbardziej prominentnymi jej postaciami I. Meštroviciem czy V. Mačkiem, a także przygodnych spotkań np. z Milovanem Đilasem czy Zbigniewem Brzezińskim.

W tym czasie ostatecznie się wykrystalizowały poglądy polityczne Radicy. Stanął na stanowisku niepodległościowym ${ }^{12}$. Z nieufnością podchodził do prób wskrzeszania idei o wspólnocie jugosłowiańskiej (co doprowadziło do rozejścia się z Mačkiem), konsekwentnie i zaciekle oskarżał komunizm Tity (w tej zaś kwestii nieco inne zdanie miał Meštrović). To z kolei nie przysparzało mu przyjaciół wśród amerykańskiego establishmentu, który w jugosłowiańskim marszałku widział wygodne narzędzie do walki z komunizmem sowieckim (nawiasem mówiąc, zachodnie demokracje w dużej mierze ponoszą odpowiedzialność za wykreowanie Tity na męża stanu). Radica przekonywał, że Tito nie zerwał ze Stalinem i że jest wciąż marionetką w rękach Moskwy. Nowsze badania historyczne pokazują, że się mylił, choć - powiedzmy wyraźnie - nie oznacza to bynajmniej, jakoby zerwał on ze wszystkimi sowieckimi praktykami sprawowania władzy.

Wspomnienia Radicy są doskonałym źródłem wiedzy - rzecz jasna: subiektywnym - na temat polityki amerykańskiej wobec bloku wschodniego. Co więcej, nadzwyczaj interesująco przedstawiają się przemyślenia dotyczące natury systemu komunistycznego i totalitaryzmu w ogóle. Czytamy np.: „faszyzm, a szczególnie komunizm opiera się na ideologiach, które dążą do całkowitego podporządkowania człowieka kłamliwym dogmatom, jego całkowite przekształcenie w coś, co jest dalekie od prawdy" (Radica 1984: 353). Negatywny stosunek do NDH, choć pojawia się rzadziej niż wobec komunistycznej Jugosławii, jest stanowczy: „Pavelić, gotując Serbom rzezie, uczynił z Chorwatów najpodlejszy bałkański margines, który swoje ideały polityczne rozwiązuje za pomocą sierpa, siekiery i bata" (Radica 1984: 386) lub „my nie możemy stać na tych samych szańcach, na których stoją ustasze, którzy są najbardziej odpowiedzialni za dzisiejsze nie

${ }^{12}$ Pogląd na ten temat najpełniej wyraził w ustępach kończących wspomnienia z lat 1944-1946 (Radica 1974: 341-348). 
do zniesienia okoliczności, w jakich znalazł się naród chorwacki - zarówno w domu, jak i w wolnym świecie!” (Radica 1984: 388).

Niemniej jednak, już od połowy lat 50. rozpoczą - podobnie zresztą jak Meštrović - współpracę z czasopismem „Hrvatska revija”13, skupiającym byłe środowiska ustaszowskie, m.in. publicystę Vinka Nikolicia ${ }^{14}$. Stevo Đurašković twierdzi, że jego zbliżenie do tych kręgów było świadome, gdyż „dąży on do uświadomienia w duchu demokracji chorwackiej inteligencji nacjonalistycznej” (Đurašković 2008: 317). Być może rzeczywiście był to czynnik decydujący, ale nie można wykluczyć także innego, że sama redakcja czasopisma - jak pisze Ivo Goldstein - „całkowicie się emancypuje od radykalnej ideologii ustaszowskiej i dąży do skupienia wokół siebie szerszego kręgu współpracowników" (Goldstein 2003: 321) ${ }^{15}$. W tym kontekście konieczne jest zweryfikowanie tezy postawionej przez Đuraškovicia, który stwierdził, że po stłumieniu chorwackiej wiosny na początku lat 70. Radica „Z politycznego centrum zupełnie przesunął się na prawo” (Đurašković 2008: 319). Jego wspomnienia akurat tego nie potwierdzają.

Jest to jeden $\mathrm{z}$ tych momentów w biografii Radicy, który wymaga dogłębnych badań. Z pozostawionych memuarów, obejmujących kilka tomów tekstów oraz komentarze rozproszone, nie dowiadujemy się, dlaczego ów zdeklarowany antyfaszysta zdecydował się na bliską współpracę z ludźmi, których wcześniej otwarcie zwalczał. W latach 40. walka ta była do tego stopnia bezkompromisowa, że - niezgodnie ze swoim antykomunistycznym poglądem - zaangażował się w budowę państwa Tity. Choć owo zbliżenie do byłych ustaszy wydawało się ryzykowne, to trzeba odnotować, że Radica nigdy nie zaakceptował poglądu faszystowskiego. Stevo Đurašković pisze o jego sprzeciwie wobec filoustaszowskiej wizji państwowej, dla

${ }^{13}$ Czasopismo pod tym tytułem powstało 1928 roku, zostało odnowione przez Nikolicia w Argentynie w roku 1951, z czasem przeniesione do Barcelony, od 1991 roku zaś wydawane ponownie w Chorwacji jako kwartalnik Macierzy Chorwackiej.

14 Nikolić w czasopiśmie „Spremnost” pisał w 1943 roku: „nowa rzeczywistość chorwacka wyraźnie i głęboko odbije się w literaturze, którą przepełni zdrowy duch ustaszowski, święta myśl Poglavnika oraz umiłowane państwo; stanie się więc literatura artystycznie silna i jednocześnie narodowa” (Matičević 2007: 331).

15 Slobodan P. Novak zauważa zmiany w poglądach Nikolicia, ale dopiero po jego powrocie do Chorwacji na początku lat 90. „Niegdysiejszy zwolennik faszystowskiej teorii literatury, w nowych okolicznościach i przed własną śmiercią sprawiał wrażenie bardziej liberalnego od licznych swoich adwersarzy z obozu komunistycznego" (Novak 2003: 286). 
której po stłumieniu chorwackiej wiosny w 1972 roku miał mieć ,ziarno więcej zrozumienia niźli wcześniej" (Đurašković 2008: 384). Kto wie, czy to nie ten właśnie sposób myślenia ukształtował późniejszą postawę pierwszego prezydenta Chorwacji Franjo Tuđmana, który - przypomnijmy - mówił, że NDH nie była tylko tworem quislingowskim i zbrodnią faszyzmu, lecz również wyrazem dążeń narodu chorwackiego do samodzielności.

Z dostępnych źródeł wnioskować jednak możemy, że byli ustasze wcale nie garnęli się do Radicy, mimo że cieszył się wielkim autorytetem. Na przykład zbiegły w 1945 roku z NDH na zachód Karlo Mirth w swojej książce Život $u$ emigraciji - w której ani słowem nie wspomina o zbrodniach w NDH - chłodniej się wyraża o Radicy aniżeli o eksustaszach, m.in. o Nikoliciu (Czerwiński 2009). Mirth we wspomnieniach odnotowuje pewne zdarzenie, które miało mieć miejsce pod koniec lat 60., kiedy do USA przyjechał z wizytą ówczesny przewodniczący Instytutu Historii Ruchu Robotniczego - Franjo Tuđman. Zdaniem autora, nie chciał się on spotkać z Radicą. Trudno stwierdzić, czy to prawda, a jeśli tak, to dlaczego Tuđmanowi - wówczas członkowi Związku Komunistów Jugosławii - nie zależało na spotkaniu z tak znaną w szerszych kręgach personą. Memuary Radicy milczą na ten temat, a Tuđman jest w nich wyraźnie nieobecny (pojawia się zaledwie trzy razy). Problem ów należałoby zbadać, gdyż być może dostarczy to odpowiedzi na pytanie, dlaczego w niepodległej Chorwacji w latach 90. o Radicy zapomniano.

Zgłębienie tej kwestii powinno również pomóc w zrozumieniu mechanizmów kształtujących poglądy prezydenta Chorwacji. Niewątpliwie wpłynęły nań środowiska emigracyjne, ale nie wiemy, czy większą rolę odegrali byli ustasze (z którymi przecież walczył jako partyzant w drugiej wojnie światowej), czy może liberalny Radica. Hybrydyczny kod emigracyjny w obu wariantach - będzie konkurował z powstającym w Socjalistycznej Republice Chorwacji innym kodem hybrydycznym próbującym godzić komunizm z ideologią narodową (w ramach ,chorwackiej wiosny”) ${ }^{16}$. We współczesnej Chorwacji oba te idiomy współistnieją obok siebie, kształtując alternatywne i trudne do pogodzenia wizje przeszłości, choć trzeba powiedzieć, że osiągnęły porozumienie w kilku aspektach. Są przede wszystkim zgodne w kwestii chorwackiej niepodległości. Oba także akcentują

16 Na ten temat cf. Czerwiński 2012 b. 
konieczność pogodzenia totalitaryzmu - już to faszystowskiego, już to komunistycznego - z tradycją liberalno-demokratyczną. Próby ujednolicenia obu nurtów znajdują się jednak jak na razie na peryferyjnych obszarach kultury (cf. Czerwiński 2013).

\section{Zakończenie}

Postawa Radicy w sposób dobitny pokazuje, że ujmowanie wojennego i powojennego pejzażu politycznego $\mathrm{w}$ ramach binarnych, przeciwstawiających sobie ustaszy i partyzantów jako reprezentantów jedynych wówczas dostępnych poglądów, jest skrajnie uproszczona. Bohater niniejszego szkicu z wielu powodów nie przystaje ani do jednego, ani do drugiego obozu. Jego chwilowe „zaczadzenie” Jugosławią Tity czy zbliżenie się do środowisk postustaszowskich były podyktowane potrzebą działania na rzecz kraju rodzinnego i oczywiście mogą podlegać krytyce. Poczynione kompromisy nie oznaczają jednak, jakoby Radica przyjął poglądy komunistyczne czy faszystowskie. Z jego wspomnień i innych dostępnych źródeł wynika, że były mu one do końca obce. Jako postać historyczna mógłby więc zostać patronem pewnej nowej wizji przeszłości Chorwacji, godzącej antagonistyczne koncepty prawicy i lewicy. Jeśli jednak absencja Radicy w zbiorowej wyobraźni wynika z niechęci do zmiany takiego paradygmatu, to należałoby przynajmniej docenić jego osiągnięcia na polu publicystyki.

Radica był człowiekiem niepokornym i upartym, hołdującym duchowi negacji charakterystycznemu dla dalmatyńskiego Splitu, w którym żywiołowo - jak na obszar Śródziemnomorza przystało - ścierały się różne postawy. Koegzystencja jego złożonej i zmiennej w czasie tożsamości lokalnej, narodowej i ponadnarodowej nadzwyczajnie pokazuje kompleksowość i bogactwo chorwackiej kultury.

\section{Literatura}

Banac I., 2006, Bogdan Radica - agonija i borba, u: Agonija Europe. Razgovori i susre$t i$, Zagreb, s. 371-378.

Benson L., 2011, Jugosławia: historia w zarysie, przeł. B. Gutowska-Nowak, Kraków. 
Bilandžić D., 1999, Hrvatska moderna povijest, Zagreb.

Czerwiński M., 2009, Iseljena Hrvatska czyli o życiu na emigracji Karla Mirtha, w: Stowiańskie diaspory, red. C. Juda, Kraków, s. 95-106.

Czerwiński M., 2012a, Semiotyka dyskursu historycznego. Chorwackie i serbskie syntezy dziejów narodu, Kraków.

Czerwiński M., 2012b, Socjalistyczny w formie, narodowy w treści. Chorwacka odmiana komunistycznej nowomowy w czasie tzw. chorwackiej wiosny, „Stylistyka” nr XXI, s. 77-98.

Czerwiński M., 2014, Do Europy tak, ale tylko z naszymi ciemiężycielami. Chorwackie spory o niedawna przeszłość, Prace Komisji Kultury Słowian PAU, Kraków (w druku).

Đurašković S., 2008, Zaboravljeni hrvatski kozmopolit Bogdan Radica, w: Dijalog povjesničara-istoričara, 10/1, red. I. Graovac, Zagreb, s. 307-327.

Goldstein I., 2003, Hrvatska povijest, Zagreb.

Jelavich B., 2005, Historia Bałkanów, przeł. J. Polak, K. Salawa, Kraków.

Meštrović I., 1969, Uspomene na političke ljude i događaje, Zagreb.

Matičević I., 2007, Prostor slobode. Književna kritika u zagrebačkoj periodici 1941-1945, Zagreb.

Novak S.P., 2003, Povijest hrvatske književnosti, Zagreb.

Radica B., 1974, Hrvatska 1945, München-Barcelona.

Radica B., 1984, Živjeti nedoživjeti. Uspomene hrvatskog intelektualca kroz apokalipsu Jugoslavije. Knjiga druga, München-Barcelona.

Radica B., 2006, Agonija Europe. Razgovori i susreti, Zagreb.

Rapacka J., 1995, Godzina Herdera: o Serbach, Chorwatach i idei jugosłowiańskiej, Warszawa.

Tanty M., 1968, Konflikty bałkańskie w latach 1878-1918, Warszawa.

Tanty M., 2003, Bałkany w XX wieku: dzieje polityczne, Warszawa. 
